\title{
Towards a Deleuzoguattarian methodology for urban design
}

\begin{abstract}
The philosophy of Gilles Deleuze and Felix Guattari (Deleuzoguattarian) is now widely thought to be apropos for today's world. This paper proposes Deleuzoguattarian philosophy as a new methodology for urban design research and practice. First, existing methodologies in the field of urban design are examined and their strengths and limitations outlined in relation to current urban problems. A reading of Deleuzoguattarian philosophy from an urban design perspective is then provided in order to propose a new methodology for research and practice. This reading mainly concentrates on the ontology and epistemology offered by the philosophy, aspects that have been neglected in the literature. The concept of territorialization as a complementary concept to assemblage theory is highlighted in order to illustrate the characteristics of the ontology and epistemology. Finally, normative goals are discussed. It is concluded that Deleuzoguattarian philosophy is not only an ethical response to modernism but is an epistemological need.
\end{abstract}

Key words:

Urban design, Methodology, Deleuze, Guattari, Epistemology, Ontology, Normative goals 


\section{Introduction:}

This paper shows the possibility for a new urban design methodology inspired by the philosophy of Gilles Deleuze and Félix Guattari or Deleuzoguattarian philosophy, as Purcell (2013) prefers. The key characteristic of this philosophy, as described in more detail below, is a move away from essentialism in acknowledgment of the constantly changing nature of all entities. In so doing, it critically employs three intellectual traditions namely Marxist political economy, Freudian psychoanalysis and poststructuralism (Colebrook, 2002; Buchanan, 2008). Deleuzoguattarian philosophy has already informed urban studies to some extent, often through borrowing specific concepts, such as Assemblage theory, and applying them to the existing processes of research and practice. However, the way in which this philosophy can ethically inform action has been underappreciated and has the potential to form a more comprehensive methodology for urban design.

Methodology is a systematic way of thinking, based on a philosophical view, that helps one to understand problems and find solutions. Any appropriate philosophical foundation for urban design methodology should be able to answer the following questions: What is the nature of urban design knowledge? How is urban design related to the external world? What allows urban design to legitimize its directions? How can urban design knowledge be acquired?

Therefore, it is necessary to consider more general issues of epistemology (studying the ways in which knowledge is acquired) and ontology (studying the perspectives on being and reality which are offered by knowledge) ${ }^{1}$ in order to answer such questions. Inappropriate answers to the aforementioned questions would exacerbate the mismatch between the knowledge and the reality of the context within which urban design functions. Madanipour believes that there is a mismatch between the orthodoxy of urban design tools and its objectives (Madanipour, 2014); Sorkin argues that urban design theory is self-referential (Sorkin, 2009); Cuthbert adds that there is not a substantial attempt in urban design to 'connect with the reality of social life' (Cuthbert, 2007b). A clear philosophical framework capable of acknowledging the complexity of urban change would therefore enhance the connection between knowledge and urban problems.

\footnotetext{
${ }^{1}$ Deleuzoguattarian philosophy would not agree with this distinction, nevertheless it can be helpful to provide better understanding of urban design. It seems that in both aspects, epistemology and ontology, urban design is chaotic.
} 
Urban design studies deal with problems caused by forces of complex political economies. However, the inherited epistemologies of urban studies are criticized for having limited capacity to deal with urban problems (Brenner \& Schmid, 2015). Contemporary cities are exemplifying the advanced political economy that is dynamically capable of capitalizing all aspects of human life (Jameson, 1991; Lazzarato \& Jordan, 2014). The mechanisms through which this system functions are selfmade, adapt over various periods of time, and vary from one location to another. The constant change of these mechanisms has the effect of making us think that the socio-political system of the current world does not follow any rules (Lazzarato, 2015). Such a dynamic complexity can only be grasped through an epistemology capable of theorizing this dynamic nature of the world.

There have already been several suggestions for different ontological shifts which may be helpful when reflecting on the dynamic complexity of cities. Among them, Deleuzoguattarian philosophy has been found to be helpful in social science (De Landa, 2006a, 2006b). In urban design discussions, Dovey (2011, 2016; Dovey \& King, 2012) adapts assemblage theory as a framework in a considerable amount of research. However, an ontological shift has only ever been discussed very briefly.

In theoretical frameworks, ontology and epistemology form foundations for values and norms. Norms are pivotal for urban design, yet they are examples of the self-made regulations (codes) of any given society. A methodology is required not only to work within such codes but also to take account of assessing and developing them. In its current state, urban design normative arguments are mostly generalized and fixed manifestations of what the majority of society want, for example in A Theory of Good City Form (Lynch, 1981), the suggested value model is justified through its common acceptance. The question here is whether or not following what the majority desires is always, or necessarily, the best direction?

The complexity in the epistemological, ontological and normative requirements of urban design makes it impossible to adapt simplified philosophical models comprehensively or effectively. However, even though the currently dominant urban design methodologies do rely on such simplified philosophical models, they cannot be entirely devalued. This paper takes an affirmative approach which neither aims to discount current theories nor to entirely accept them. Instead, it aims to increase awareness of the capabilities of the theories, challenge the limitations, and suggest ways forward. Therefore, as a conjunction of critical thinking with creativity (Braidotti, 2013), an affirmative approach opens new perspectives when an established way of thinking faces its limits. This paper applies an affirmative approach to urban design methodologies, suggesting that Deleuze and Guattari's philosophy can contribute to the current processes of urban design research and practice.

\section{Examples of current methodologies}

There are limited texts contributing to the understanding of ontological and epistemological aspects of urban design. Within the core body of urban design (Foroughmand Araabi, 2015) and forty important urban design texts (Cuthbert, 2007a), the following texts have significant contributions: Broadbent (1995), Moudon (1992) and Cuthbert (2007). Almost all these texts use simplified philosophical frameworks borrowed from classical philosophy. 
Broadbent (1995) introduces three ways of thinking in urban design: rationalism ${ }^{2}$, which trusts pure rational reasoning, discrediting human experience as a way of producing valid knowledge; empiricism, which values human senses; and pragmatism, which focuses on whatever means can meet the intended goals. Rationalism and empiricism both try to discover the rules of the world through contradictory epistemologies; one relying on observation and the other relying on logical reasoning. In this sense, they share an ontological assumption that the world is following set laws. Considering the dynamic nature of the context within which urban design operates, both rationalism and empiricism have limited applications. Pragmatism is also limited as it only focuses on solving the problems in hand, refusing to tackle ontological and epistemological questions. Not going beyond the scope defined by the problems blocks critical thinking and can exacerbate the mismatch between urban design objectives, tools and reality.

These modes of thinking all fall sort of being capable of theorizing actual urban problems. Broadbent expands his categorization in order to classify other philosophical traditions. He considers 'Marxist ideology' as neo-rationalist and 'urban realists' as neo-empiricists. This is pigeonholing new modes of thinking into the classical categories.

Broadbent's classifications seem to be both detached from the traditions of urban design thinking modes and unable to provide a full picture of the dynamic nature of cities. The classical distinction between rationalism and empiricism does not provide an adequate analytical tool to explain the complexity of urban design problems. However, other urban design commentators have been aware of the importance of acknowledging the complexity of cities. Jane Jacobs, in the last chapter of her seminal book, explains the characteristics of this organized complexity (Jacobs, 1992). The conceptualising of urban problems as 'wicked problems' (Rittel \& Webber, 1973) and the application of this understanding in urban design (Lang, 2005; Biddulph, 2012; Carmona, 2014) illustrates an acknowledgement of the existing complexity. Nevertheless, none of the discussed methodologies has yet been seen to be capable of dealing with or theorizing such complexity (Foroughmand Araabi, 2017a).

Anne Vernnerz Moudon (1992) draws an epistemological map of urban design knowledge in her paper 'A Catholic Approach To What An Urban Designer Should Know'. Moudon's paper has been considered as one of the most important texts on urban design theories, covering a wide range of key research strategies and urban design texts at the time (Larice \& MacDonald, 2007, p. 438; Inam, 2014). In comparison to Broadbent, Moudon's categorization of urban design research strategies is closer to the reality of the literature because it studies what urban design knowledge is, as well as how the knowledge is acquired. Nonetheless, she does not cover the ontological aspect of urban design.

Moudon categorizes theories of urban design based on different criteria, two of which are related to the subject of this paper: theory strategies and modes of inquiry. Both of these categories explain methods and strategies by which urban design research can be developed and urban design knowledge can be acquired. She introduces three research strategies: literary approach relies on literature searches, references and reviews, and archival work of all kinds; phenomenological approach is a holistic view of the world, the practice of which depends entirely on the researcher's total experience, describing events with his or her feelings, senses and knowledge; and positivism

\footnotetext{
${ }^{2}$ Faludi considers rationalism as a methodology (Faludi, 1986).
} 
where knowledge is acquired through studying natural phenomena and is verified by empirical science (Moudon, 1992). In comparison to Broadbent, Moudon goes a step further in describing strategies for developing knowledge.

Moudon then introduces three modes of inquiry, which are: historical-descriptive, research that studies historical events; empirical-inductive, generalizing the knowledge obtained from observation of a phenomenon; and theoretical-deductive quantitative research (Moudon, 1992). Moudon believes that because urban design problems are highly complex, the theoretical-deductive mode is rarely found in urban design (Moudon, 1992). Her classification is a helpful tool in mapping the knowledge, but it does not provide a framework for the practice of urban design. Her model also detaches theories from their social contexts.

More recently, Cuthbert discussed three dominant intellectual traditions which he considers to be influential philosophical and practical modes: semiotics, phenomenology and Marxian political economy (Cuthbert, 2007a, p. 65). Semiotics presupposes a structure for the outside world and cities. Semiotic epistemology is informed by the science of studying signs. Despite its contributions (Floch, 1988), semiotics has not become a dominant mode of thinking in current urban design.

Phenomenology is a comprehensive philosophy with a clear ontology and epistemology based on the spatial existence of human beings and the historical nature of knowledge. Phenomenology has had a significant contribution to urban design, particularly in discussions around the sense of place (Aravot, 2002; Norberg-Schulz, 1980; Relph, 1976; Trigg, 2012). Phenomenological methodology can be criticized because it separates the ego (exemplified in the concept of Dasein $^{3}$ ) from its surroundings by considering a transcendental stance for the human ego (Buchanan, 2008). Its application in urban design often focuses on perceived experiences of space instead of seeing the observer as an element of a bigger assemblage.

Marxist political economy conceptualizes the world as the resource used for the conflict between social classes, which results in unequal distribution and exploitation (Castree, 2000). Nature is seen as a resource for developing wealth and power. In this philosophy, the epistemology relies on the concept of conflicts between social classes. Marxist political economy, and its application to cities (Castells, 1977; Harvey, 1989; Lefebvre, 2011), has contributed to urban design studies (Cuthbert, 2007a; King, 1996). It has a highly critical stance with suspicions about whether creativity within the existing system can bring about any real change, suggesting that urban design could be a servant of neoliberal forces (Foroughmand Araabi, 2017b). The possibility of making change is a prerequisite for critical urban design. This paper proposes an affirmative approach enabling the opportunity for both making change from within the system and challenging the system in its totality.

None of the discussed methodologies seems to be capable of fully acknowledging the ever-changing characteristics of urban problems. This ultimately weakens the connection between urban design and the social realities. In what follows, the concept of territorialization is discussed as being capable of overcoming this limitation.

\footnotetext{
${ }^{3}$ Heideggerian term for being-there conceptualszing human being as a spatial phenomenon (Heidegger, 2013).
} 


\section{Territorialization}

Current methodologies rely on fixed assumptions about the outside world in their ontology and have fixed methods for achieving knowledge in their epistemology. Deleuzoguattarian philosophy proposes a becoming-in-the-word ontology (going beyond the being-in-the-world ontology offered by phenomenology). Dovey considers this shift to be capable of rescuing place studies from essentialism (Dovey, 2010). Deleuzoguattarian theory is transferred to urban studies mostly through assemblage theory. 'Assemblage is the productive intersection of a form of content (actions, bodies and things) and a form of expression (affects, words and ideas)' (Buchanan, 2015, p. 390). Assemblages emerge through territorialization processes when connections between entities produce an arrangement that functions in a specific way (Deleuze \& Guattari, 2012). As any entity belongs to various assemblages and is affected by different forces, they are experiencing different territorializations at any given time. Territorialization does not happen only in physical space, but it also happens in psychological space. In fact, territorialization is a specific form of becoming.

Becoming is the key characteristic of all entities in this ontology. But when a mechanism is becoming more rigid, more controlled, more striated and defined, it is called territorialization in Deleuze and Guattari's words. This is then followed by another process of becoming which frees and flees, undoing the existing structure within the mechanism or deterritorializes it. The deterritorialized entity will then start a new territorialisation and another process of becoming because nothing can remain absolutely un-territorialized. This territorialisation, which happens after deterritorialization, is called reterritorialization (Holland 1991). The tensions between territorialisation, deterritorialization, and reterritorialization are seen as beyond dialectic and often co-exist or occur simultaneously.

Deterritorialization, whether partly or entirely, de-codifies the given assemblage. In this respect it 'indicates the creative potential of an assemblage' (Parr, 2010, p. 69) and it is more capable of finding new ways when a blockage appears in thinking (Massumi, 1996). This aspect of deterritorialization will be discussed later in regard to urban design norms. Territorialization provides the basic vocabulary for the suggested methodology, which is described in four of Deleuze and Guattari's collaborations outlined below.

Anti-Oedipus: Capitalism and Schizophrenia is Deleuze and Guattari's first co-authored book, published in 1973. In Anti-Oedipus they start by criticizing the widely accepted psychoanalytic approach where everything is seen from the lens of the Holy family, meaning the role of father, mother and son. Deleuze and Guattari replace this Freudian model with a more complex and less structured concept. They see the individual and the social unconscious as a product of the combination (assemblage) of history, society, physiology and so on. In their view, the unconscious is not separate from the conscious nor does it follow any fixed model; rather it makes its own regulations. At a social level, this critique explains how capitalism forms (territorializes) the unconsciousness and how interests (what people like) are formed by capitalism or other forms of power. Anti-Oedipus, as Foucault states in his preface to the English edition, can be seen as a work of art, 'an "art"... informed by the seemingly abstract notions of multiplicities, flows, arrangements ${ }^{4}$

\footnotetext{
${ }^{4}$ In French agencement which is translated to assemblage in A Thousand Plateaus. 
[assemblages], and connections. The analysis of the relationship of desire to reality and to the capitalist “machines" yields answers to concrete questions' (Deleuze \& Guattari, 2012).

The concept of deterritorialization renders this philosophical capable of explaining many bottom-up or informal movements, such as 1968's uprising, which cannot be understood as an Oedipal desire to kill the father (represented by the government in 1968) and conquer his position (Buchanan, 2008). Anti-Oedipus describes the territorialization of people, society and nature as interconnected. In this way, territorialization does not have a set goal or a fixed regulation, rather it continually alters based on the existing condition. In this respect, it is an anti-essence ontology.

The anti-essence ontology of Anti-Oedipus can also replace the current approaches to time and space as fundamental essences of urban design (for example in Bacon, 1976; Giedion, 2009; Madanipour, 1996). For Deleuze and Guattari, the perceiver and the assemblage are not discrete from the very concept of time and space. Kant added the subjective ' $I$ ' to experience by considering the mind's structure (structures and features such as time and space). Deleuze and Guattari, on the contrary, subtract the subject from experience by considering the ego to be a social production (Holland, 2013, p. 10). From this perspective, phenomenology is misled by an overemphasis on the ego as something discrete from experience (Buchanan, 2008).

In Anti-Oedipus the main concepts of Deleuze and Guattari's philosophy were formed, but their seminal book is the second volume of Capitalism and Schizophrenia, called $A$ Thousand Plateaus ${ }^{6}$ (1980). The way in which the book is written enables it to be a functioning form in itself. Rather than being a mere representation of the world, this book invites the readers to have new encounters with the world. A Thousand Plateaus employs a spatial logic (territoriality) of multiple sections (plateaus) as the method of organization, explained as rhizome (Young, 2013, p. 314). Rhizome is a central concept of their philosophy because for them, connections replace the idea of any fixed realities. The nature of connections, as Deleuze and Guattari explain, is rhizomic. They define rhizome as opposed to fixed structural or hierarchical views (Deleuze \& Guattari, 2002, pp. 3-28).

Rhizome is a philosophical model for explaining the world and is deeply connected to the concept of assemblage. In fact, it is a spatial model of the philosophy. Examples of rhizome in nature, like ginger, grow based on the opportunities provided by the context. Thus, they do not embody any predetermined shape and thus co-evolve with their surroundings. However, this goes beyond physical entities. One of the key results of having a rhizomic view is being able to see connections between different chaotic aspects of the cosmos. To start with, the connection between human and non-human. In other words, chemical and biological systems (including animals and humans) are interconnected. Since continuous change is happening in every territory (system), there is no law that is followed by, or could be applied to, a system at all times. However, there are mechanisms in common between different territories. The organization of self-organizing systems emerges through the experience (life) of that system. In this regard, Deleuze and Guattari replace the law with the

\footnotetext{
${ }^{5}$ Machine in Deleuze and Guattari's philosophy means a mechanism in that its parts are working together to produce something. Machines are defined by their goals. Machines are always connected to other machines. So they are more like dynamic mechanisms rather than merely mechanical machines.

${ }^{6}$ After Anti-Oedipus and before $A$ Thousand Plateaus they published Kafka, which has lots to offer in relation to literature. But since the key points of that book are reflected in their later works and also because Kafka is not part of their project Capitalism and Schizophrenia, this book is not considered here.
} 
life $^{7}$ of the system (Holland, 2013, p. 21). In chapter 11 of A Thousand Plateaus, Deleuze and Guattari discuss spatial and temporal aspects of territorialization, along with assemblage. They suggest an epistemology that thinks with the cosmos rather than thinking about it, in the sense that thinking is territorialization. This forms their concept of becoming which reflects the ever-changing nature of entities. However, becoming is happening in different ways at various speeds. This resonates strong similarities with Christopher Alexander's conceptualization of cities as non-tree-like structured entities (Alexander, 1965). In this respect, Alexander is the ancestor of rhizomic thinking in relation to urban form and functions. Nonetheless, his ontology advocates a 'timeless way' (Alexander, 1979) and 'opposing systems' (Alexander, Neis, \& Alexander, 2012) both of which resonate essentialist philosophy.

Ten years after A Thousand Plateaus, Deleuze and Guattari wrote What is Philosophy, first published in 1991. This book could be seen as an ontological statement where they discuss how concepts cut through the chaos (the world) in order to make meaning out of (territorialize or deterritorialize) the world (Massumi, 1996). In What is Philosophy, Deleuze and Guattari differentiate between art, science and philosophy. Philosophy and science are seen as approaches to working with 'chaos' and attempting to bring order to it. Both are creative modes of thought, and both are complementary to each other, as well as to the third mode of creative thought - art (Bonta \& Protevi, 2004, p. 29). What is Philosophy contributes to Deleuzoguattarian ontology by describing concepts as key elements of creativity when dealing with the world in a non-essentialist way. There is no formula for the creation of concepts, they can appear in response to what human beings perceive as problems. This approach would condemn any attempt to understand urban problems through fixed processes and parameters.

The concept of territorialization contributes to assemblage theory in at least three ways (Buchanan, 2015). Firstly, territorialization highlights that components of assemblages are not necessarily physical objects with social functions, as argued in Latourian actor-network-theory (Latour, 1992). Secondly, the concept of territorialization helps us understand that assemblages are not necessarily socio-historical networks, as argued by Delanda (2006a), as even influential social assemblages can appear suddenly. Finally, because assemblage theory is about connections between entities, it has an outward view (Young, 2013). Territorialization enables us to acknowledge the mutual influence of the inside and the outside of entities.

Territorialization, through its ontology and epistemology, challenges pre-supposed structures thus distinguishing itself from other methodologies. Deleuzoguattarian thinking is post-structuralist in two senses; Post-structuralist, in the sense of extending a transdisciplinary reach of theory; And Post-structuralist in the sense of 'rescuing theory and theory-informed research from the very "linguistic turn" for which structuralism has been primarily responsible, and putting them back in touch with pressing problems in the outside world' (Holland, 2013, p. 148). Deleuze's theory of difference (Deleuze \& Patton, 2004) is highly critical of structuralism. Structuralists argued that a system of difference is necessary in order for a single being to be known. A structure that differentiates must first exist in order to have a history of something (Colebrook, 2002, p. 9). Contrary to this philosophical view, Deleuze suggests the concepts of difference in itself and

\footnotetext{
${ }^{7}$ Deleuze and Guattari develop a vocabulary that emphasizes how things connect rather than how they 'are', and tendencies that could evolve in creative mutations rather than a 'reality'. They prefer to consider things not as substances, but as assemblages or multiplicities (Parr, 2010, p. 174).
}

Page $\mid 8$ 
repetition for itself. This means that repetition and difference exist independently of any fixed system or structure and enable an understanding of entities in relation to constant change.

Urban design has been affected by both structuralism and post-structuralism. Structuralism has influenced urban design in its understanding of urban form (Rossi, 1982), conceptualization of urban design theory, and its professionalism (Gosling \& Gosling, 2003) - the way urban design became a fairly independent discipline. Urban design thinking has been influenced by post-structural concepts of space, power, psychology and politics. Many believe that urban design emerged in response to modernism and has been informed in particular by critiques of post-war rapid urbanization (Gosling \& Gosling, 2003; Lang, 2005). Urban design's core principle was to criticise top-down modern urbanism for its oversimplified understanding of human beings and cities. Le Courbusier's work has come to symbolize this top-down modernist approach. Jacobs (1992) and Alexander (1965; Alexander, Ishikawa, \& Silverstein, 1977), amongst many others, tried to replace this simplified model with a better understanding of cities as entities which can never fully be understood, echoing Deleuzoguattarian thinking. The concept of territorialisation can help urban design by providing ontological and epistemological frameworks that are able to bypass essentialism yet work with the existing forms. These frameworks can help enhance our understanding of the ways in which the social and physical structures of cities emerge as a result of different assemblages unfolding in response to the specific contexts. This does not negate the physical form or structures of cities, rather it sheds light on the dynamic processes which are involved in continual urban reformation. In this respect, rhizomic forces produce structures and patterns. But none of them are abstract or a result of divine (or pre-set) models. This thinking framework links urban complex theories and systems thinking and has been coupled with studies on urban territories (Bura, Guérin-Pace, Mathian, Pumain, \& Sanders, 2010) and urban subcultures (Daskalaki \& Mould, 2013). In fact trritoriology is now argued to be akin to biology, zooethology and human ethology (Brighenti, 2010).

Deleuze and Guattari's work is comprehensive and rich in content. It is not possible to summarize it in such a short paper. However, a key characteristic is that all entities are seen to be in a state of continuous change. The necessity of seeing cities as continually changing entities (Hillier, 2005) has not yet been reflected in urban design methodologies. Deleuzoguattarian philosophy is seen here not only as an ethical response to modernism but as an epistemological need.

\section{Deleuzoguattarian thinking in urban studies, planning and design}

The influence of Deleuze and Guattari's philosophy may have been slow in coming yet it appears to be crucial. It is hard to follow their influence for at least two reasons. First, because they have an influence on an extraordinarily wide range of disciplines. Second, because some of their influence was indirect (Holland, 2013, pp. 139-148). Their work is currently influential in areas ranging from science, geography, social science, art and politics (Young, 2013).

Deleuzoguattarian thinking has been widely applied in urban studies (Farias \& Bender, 2010; McFarlane, 2011a, 2011b; Rankin, 2011) but less and less in urban planning and design. In this respect, the ways in which Deleuzoguattarian philosophy informs urban design norms has remained underdeveloped. This paper begins to explore the potential for this philosophy to form new urban design norms. 
It has been regularly argued that urban design as a discipline has developed between planning and architecture (Madanipour, 2014). Both fields have benefited more from Deleuzoguattarian thinking than urban design. Recently, planners such as Wood (2009), Hillier (2005, 2011) and Purcell (2013) pay attention to Deleuze and Guattari's work. Wood tries to demonstrate that Deleuzoguattarian philosophy provides a new resource and creates a new direction for understanding the role of urban planning in society (Wood, 2009). Hillier uses Deleuze and Guattari along with Foucault to explore strategic planning as a form of strategic navigation (Hillier, 2011). Purcell, in his inspiring paper, reviews the literature and shows potential for using Deleuze and Guattari's philosophy for planning by paying attention to their political vision, 'which is a revolutionary agenda that aims at a condition of radical freedom for humans beyond the state and capitalism' (Purcell, 2013, p. 20). Rydin argues that this philosophy opens up ways of considering the materiality of cities more in planning (Rydin, 2014). Nevertheless, the majority of planning commentators have not explored the philosophy on a methodological level (Foroughmand Araabi, 2014).

In architecture, there has been a considerable number of Deleuzian-inspired works (Ballantyne, 2007; Brott, 2011; Frichot, 2013). This is mainly because of Deleuze's 'adaptation of the architectural image of thought' in his book The Fold (Deleuze, 2006) and his attention to space (Holland, 1999, p. 144). Nevertheless, the influence on architecture does not appear to have spread to urban design.

It is often Deleuze's collaborations with Guattari which are referenced in urban design literature. Kim Dovey, the dominant voice here, applies the concept of assemblage, mostly from $A$ Thousand Plateaus, in studying sense of place (Dovey, 2010); informal settlements (Dovey, 2012; Dovey \& King, 2012); as a critical urban theory (Dovey, 2011); and as a model to understand urban design concepts (Dovey, 2016). Ian Bentley uses the Deleuzoguattarian concept of the Desiring-Machine to explain subjectivity and public interest as being actively constructed (Bentley, 1999, p. 53). Nan Ellin suggests that Deleuze and Guattari's work can be seen as 'social theory analogue to' Integral Urbanism because it is not concerned with opposing binaries (Ellin, 2006, p. 84). Thus far, Deleuzoguattarian philosophy has been applied with limited scope to a wide range of urban design topics. Emerging from these cases are the following urban design areas where Deleuzoguattarian thinking has been found helpful:

- When addressing complex issues where a linear cause and effect relationship does not sufficiently reflect the actual context, such as the emergence of the sense of place as opposed to something that can be crafted by fully the professional (Dovey, 2010) or density (Dovey \& Pafka, 2014).

- When combining critical urban thinking with the notion of urban change (Dovey, 2011; Ellin, 2006; McFarlane, 2011a).

- When incorporating informal urbanism (Buser, 2014; Dovey, 2012; Dovey \& King, 2012; Van Wezemael, 2008).

Deleuzoguattarian thinking, as evinced by these themes, is capable of acknowledging the connections between seemingly disparate entities and continuous change in order to better understand the fluidity, multiplicity, vagueness, and what some call the messiness of life (Coleman \& Ringrose, 2013, p. 5). Nevertheless, Deleuze and Guattari's philosophy is still not applied on a methodological level here. For Deleuze and Guattari, 'philosophy is ontology' (Parr, 2010, p. 196) in the sense that they reject any metaphysics or transcendental philosophy in order to focus on the 
real, 'real as a process' (Parr, 2010, p. 196). This view helps us to deal with problems in a more realistic manner as well as challenging urban design orthodoxies, and blockages in thinking (Massumi, 1996).

\section{Finding directions for action}

Planning and design propose actions and changes to cities, unlike disciplines such as geography, sociology and urban studies that aim to understand societies and cities. But how is this change justified? An adequate methodology should be able to direct such an action. Normative debates in urban design are considered to do so (Gosling \& Gosling, 2003; Inam, 2011; Lynch, 1981; Shane, 2005; Sternberg, 2000). Following the concept of territorialization described earlier, urban design normative would be the practice of territorialization and deterritorialization.

Norms and social values can be seen as codes of a given assemblage. If urban design functions for the favour of established codes, it can therefore be seen as a means for territorialization. This is the main way of advocating the existing social norms. These norms could be established by different sectors of a society. Values such as sustainability, beauty and justice are examples of codes that are now widely accepted. When urban design functions as a means for territorialization, it is necessary for the designer to consider the codes as changing phenomena. In this way, no form of knowledge ever reached its final state. Rather, knowledge should constantly be co-produced with the life of the given assemblage (society). There is always a multiplicity of codes within groups at various levels.

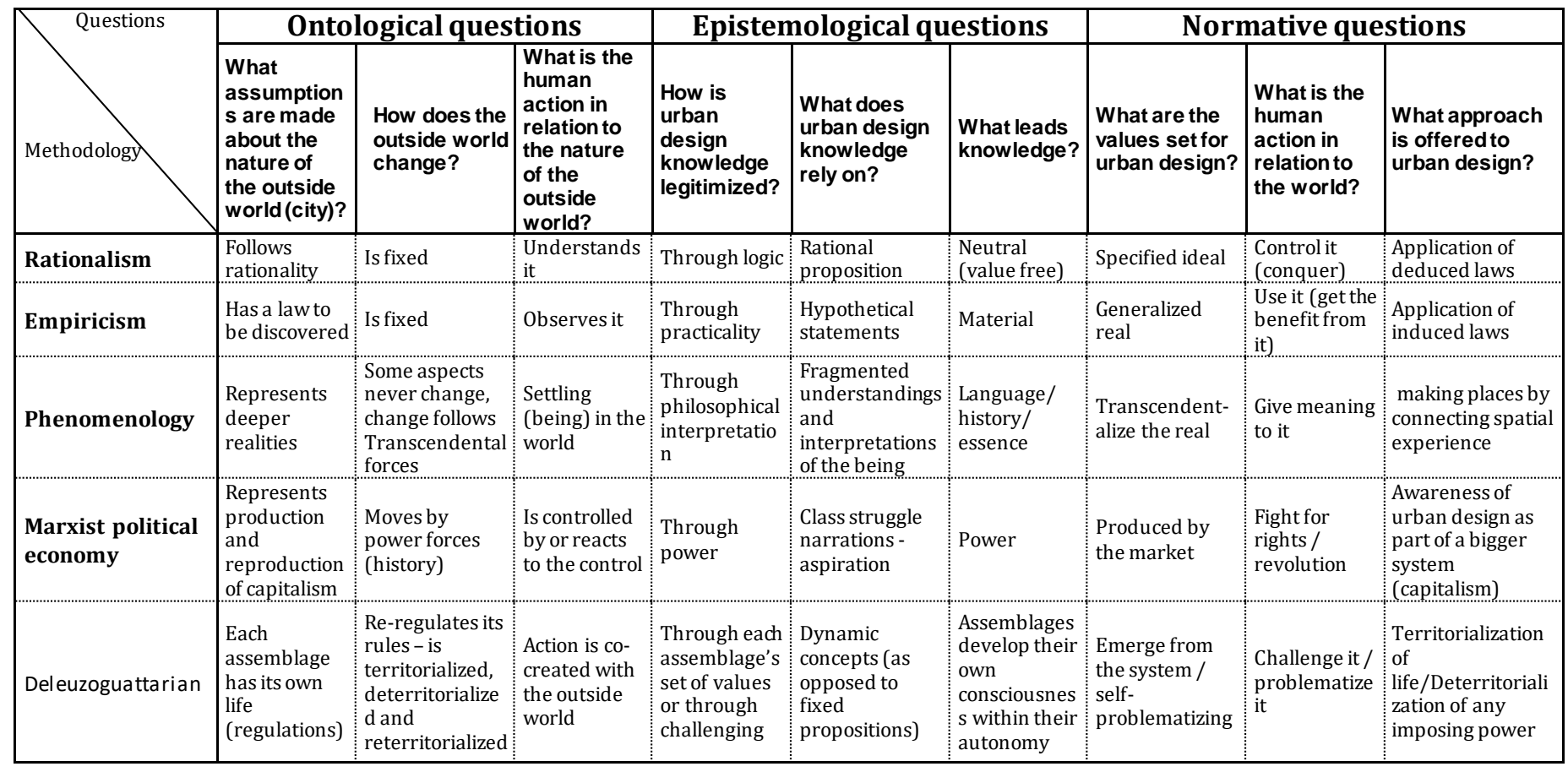


On the other hand, when urban design aims to challenge the accepted values of a society, it can be conceptualized as an example of deterritorialization. Deterritorialization produces difference, new forms, functions and expressions. In his preface to Anti-Oedipus, Foucault pictures deterritorialization as an ethical act of challenging the established discourse for the favour of minorities (Deleuze \& Guattari, 2012). It is necessary to highlight that deterritorialization is not an absolute demolishing of the codes but is often partial reordering. In regard to deterritorialization, design is supposed to bring about something new benefiting those who are forgotten by the existing regulations. In this regard deterritorializing through urban design follows critical creativity (Foroughmand Araabi, 2017b). It is critical as it acts for the sake of minorities, forgotten groups and values. And it is creative as it creates new forms and processes.

A design based on deterritorialization will ultimately be either absorbed (normalized) or rejected by society as nothing remains new or alternative for ever. Following this conception, creativity is not valid merely for the sake of producing the new, rather it gains its ethical value through challenging power. Thus, creativity must be critical otherwise it will produce new forms of the established regulations. Error! Reference source not found. summarizes this section and provides a comparison between Deleuzoguattarian methodology and the current dominant methodologies of urban design.

\section{Conclusion}

Focusing on the concept of territorialization, this paper provides a basic ontological, epistemological and normative vocabulary for a Deleuzoguattarian methodology. Comparisons between dominant methodologies show the advantages of a Deleuzoguattarian methodology. This methodology can provide a stronger connection between knowledge and real urban problems by both better explaining the nature of urban design problems and providing critical justifications for design. The methodology can thus be applied to urban design research and practice which tries to understand urban problems as it has the capacity to acknowledge multi-level forces that shape and change cities.

Normative aspects of urban design are defined in two ways here; first as territorialisation (following the existing codes/values), second as deterritorialization (challenging the established codes/values). The paper proposes that deterritorialization is ethical when aiming to benefit minorities and forgotten groups. In this respect, the contribution of this paper is one of providing a new and ethical normative for research and practice.

The paper invites a broader understanding of urban processes than the existing theories, in particular assemblage theory. Although the paper does examine the existing methodologies of the field of urban design, it does not suggest a paradigm shift. In a paradigm shift, the new paradigm and the old one cannot co-exist. Incommensurability of the new and old paradigm is one of the fundamental conditions of a paradigm shift (Kuhn, 1996). Rather, this paper, employs an affirmative approach offering a framework that could be used alongside other frameworks. Neither is the methodology offered exclusive to urban design, as it questions any strict separation between urban design and other disciplines. Here, territorialization is seen as going beyond existing boundaries. 
Traditionally, urban design research and practice rely excessively on snapshots of the system. For example, in masterplanning, the survey phase represents the assumption that there is a law (or set regulations) in the urban system which can be discovered. The suggested epistemology, however, broadens the scope. One example of the way in which this methodology could be applied is when working with real-time big-data analyses as a way to understand and learn about the life of dynamic systems. The proposed methodology would also encourage researchers and practitioners to move on when there is a blockage in thinking about, and working with, urban problems rather than reverting to orthodox ways of thinking. Deleuze and Guattari's philosophy calls for continual fresh encounters with the world over and over. Deleuzoguattarian philosophy is therefore seen here not only as an ethical response to modernism but as an epistemological need.

\section{References:}

Alexander, C. (1965). A city is not a tree. Architectural Forum, 122(1 \& 2), 58-62.

Alexander, C. (1979). The Timeless Way of Building. New York: Oxford University Press.

Alexander, C., Ishikawa, S., \& Silverstein, M. (1977). A pattern language: towns, buildings, construction. New York: Oxford University Press.

Alexander, C., Neis, H., \& Alexander, M. M. (2012). The Battle for the Life and Beauty of the Earth: a struggle between two world-systems. New York: Oxford University Press.

Aravot, I. (2002). Back to Phenomenological Placemaking. Journal of Urban Design, 7(2), 201-212. https://doi.org/10.1080/1357480022000012230

Bacon, E. N. (1976). Design of Cities (Rev. ed). New York: Penguin Books.

Ballantyne, A. (2007). Deleuze and Guattari for Architects. London ; New York: Routledge.

Bentley, I. (1999). Urban Transformations, power, people and urban design. London: Routledge.

Biddulph, M. (2012). The Problem with Thinking about or for Urban Design,. Journal of Urban Design.

Bonta, M., \& Protevi, J. (2004). Deleuze and Geophilosophy: a guide and glossary. Edinburgh: Edinburgh University Press.

Braidotti, R. (2013). The Posthuman. Cambridge: Polity Press. Retrieved from about:home

Brenner, N., \& Schmid, C. (2015). Towards a new Epistemology of the Urban? City: Analysis of Urban Trends, Culture, Theory, Policy, Action, 19(2-3), 151-182.

https://doi.org/10.1080/13604813.2015.1014712 
Brighenti, A. M. (2010). On Territorology: Towards a General Science of Territory. Theory, Culture \& Society, 27(1), 52-72. https://doi.org/10.1177/0263276409350357

Broadbent, G. (1995). Emerging Concepts in Urban Space Design. Taylor \& Francis.

Brott, S. (2011). Architecture for a Free Subjectivity: Deleuze and Guattari at the horizon of the real. Farnham, Surrey; Burlington, VT: Ashgate.

Buchanan, I. (2008). Deleuze and Guattari's Anti-Oedipus: a reader's guide. London; New York: Continuum.

Buchanan, I. (2015). Assemblage Theory and Its Discontents. Deleuze Studies, 9(3), 382-392. https://doi.org/10.3366/dls.2015.0193

Bura, S., Guérin-Pace, F., Mathian, H., Pumain, D., \& Sanders, L. (2010). Multiagent Systems and the Dynamics of a Settlement System. Geographical Analysis, 28(2), 161-178. https://doi.org/10.1111/j.1538-4632.1996.tb00927.x

Buser, M. (2014). Thinking through nonrepresentational and affective atmospheres in planning theory and practice. Planning Theory, (13), 227-243. https://doi.org/10.1177/1473095213491744

Carmona, M. (2014). The Place-shaping Continuum: A Theory of Urban Design Process. Journal of Urban Design, 19(1), 2-36. https://doi.org/10.1080/13574809.2013.854695

Castells, M. (1977). The Urban Question, A Marxist Approach, (Vol. first). Edward Arnold.

Castree, N. (2000). Marxism and the Production of Nature. Capital \& Class, 24(3), 5-36. https://doi.org/10.1177/030981680007200102

Colebrook, C. (2002). Understanding Deleuze. Crows Nest, N.S.W: Allen \& Unwin.

Coleman, R., \& Ringrose, J. (Eds.). (2013). Deleuze and Research Methodologies. Edinburgh: Edinburgh University Press.

Cuthbert, A. (2007a). The Form of Cities: Political Economy and Urban Design.

Cuthbert, A. (2007b). Urban Design: requiem for an era - review and critique of the last 50 years. URBAN DESIGN International, 12, 177-223. 
Daskalaki, M., \& Mould, O. (2013). Beyond Urban Subcultures: Urban Subversions as Rhizomatic Social Formations: Urban subcultures and subversive social formations. International Journal of Urban and Regional Research, 37(1), 1-18. https://doi.org/10.1111/j.14682427.2012.01198.x

De Landa, M. (2006a). A New Philosophy of Society: assemblage theory and social complexity. London; New York: Continuum.

De Landa, M. (2006b). Deleuzian Social Ontology and Assemblage Theory. In Deleuze and the Social (pp. 250-266). Edinburgh: Edinburgh University Press.

Deleuze, G. (2006). The fold: Leibniz and the Baroque (Rev. ed.). London; New York: Continuum.

Deleuze, G., \& Guattari, F. (2002). A Thousand Plateaus Capitalism and Schizophrenia. London: Continuum.

Deleuze, G., \& Guattari, F. (2012). Anti-Oedipus: capitalism and schizophrenia. (M. Seem \& H. R. Lane, Trans.). London; New York: Continuum.

Deleuze, G., \& Patton, P. (2004). Difference and Repetition. London: Continuum.

Dovey, K. (2010). Becoming Places: urbanism/architecture/identity/power. London; New York: Routledge.

Dovey, K. (2011). Uprooting Critical Urbanism. City, 15(3-4), 347-354. https://doi.org/10.1080/13604813.2011.595109

Dovey, K. (2012). Informal Urbanism and Complex Adaptive Assemblage. International Development Planning Review, 34(4), 349-368. https://doi.org/10.3828/idpr.2012.23

Dovey, K. (2016). Urban design thinking: a conceptual toolkit. London; New York: Bloomsbury Academic, An imprint of Bloomsbury Publishing Plc.

Dovey, K., \& King, R. (2012). Informal Urbanism and the Taste for Slums. Tourism Geographies, 14(2), 275-293. https://doi.org/10.1080/14616688.2011.613944

Dovey, K., \& Pafka, E. (2014). The Urban Density Assemblage: Modelling multiple measures. URBAN DESIGN International, 19(1), 66-76. https://doi.org/10.1057/udi.2013.13 
Ellin, N. (2006). Integral Urbanism. Routledge.

Farias, I., \& Bender, T. (2010). Urban Assemblages: how actor-network theory changes urban studies. London; New York: Routledge.

Floch, J.-M. (1988). The contribution of structural semiotics to the design of a hypermarket. International Journal of Research in Marketing, 4(3), 233-252. https://doi.org/10.1016/S0167-8116(88)80007-7

Foroughmand Araabi, H. (2014). Deleuze and Research Methodologies: The impact on planning. City, 18(4-5), 589-593. https://doi.org/10.1080/13604813.2014.939508

Foroughmand Araabi, H. (2015). A typology of Urban Design theories and its application to the shared body of knowledge. URBAN DESIGN International. https://doi.org/10.1057/udi.2015.6

Foroughmand Araabi, H. (2017a). Multiple expectations: assessing the assumed roles of theory in relation to urban design. Journal of Urban Design, 22(5), 658-669. https://doi.org/10.1080/13574809.2017.1298402

Foroughmand Araabi, H. (2017b). Schools and skills of critical thinking for urban design. Journal of Urban Design, 1-17. https://doi.org/10.1080/13574809.2017.1369874

Frichot, H. (Ed.). (2013). Deleuze and architecture. Edinburgh: Edinburgh University Press.

Giedion, S. (2009). Space, Time and Architecture: The Growth of a New Tradition (Vol. fifth). Harvard University Press.

Gosling, D., \& Gosling, M. C. (2003). The Evolution of American Urban Design. Wiley.

Harvey, D. (1989). The Urban Experience. Baltimore: Johns Hopkins University Press.

Heidegger, M. (2013). Being and Time. (J. Macquarrie \& E. Robinson, Trans.) (35. reprint). Malden: Blackwell.

Hillier, J. (2005). Straddling the Post-Structuralist Abyss: Between Transcendence and Immanence? Planning Theory, 4(3), 271-299. https://doi.org/10.1177/1473095205058497 
Hillier, J. (2011). Strategic navigation across multiple planes: Towards a Deleuzean-inspired methodology for strategic spatial planning. Town Planning Review, 82(5), 503-527. https://doi.org/10.3828/tpr.2011.30

Holland, E. (1991). Deterritorializing 'Deterritorialization': From the 'Anti-Oedipus' to 'A Thousand Plateaus'. University of Wisconsin Press, 20(66), 55-65.

Holland, E. (1999). Deleuze and Guattari's Anti-Oedipus: introduction to schizoanalysis. London; New York: Routledge.

Holland, E. (2013). Deleuze and Guattari's A thousand plateaus: a reader's guide. New York: Bloomsbury Academic.

Inam, A. (2011). From Dichotomy to Dialectic: Practising Theory in Urban Design. Journal of Urban Design, (16:02), 257-277.

Inam, A. (2014). Designing Urban Transformation. Routledge.

Jacobs, J. (1992). The Death and Life of Great American Cities (Vintage Books ed). New York: Vintage Books.

Jameson, F. (1991). Postmodernism, or, The cultural logic of late capitalism. London: Verso.

King, R. (1996). Emancipating Space: Geography, Architecture, and Urban Design. Guilford Press; First Edition edition.

Kuhn, T. S. (1996). The Structure of Scientific Revolutions. Chicago, IL: University of Chicago Press. Lang, J. (2005). Urban design : a typology of procedures and products : illustrated with over 50 case studies. Architectural Press,.

Larice, M., \& MacDonald, E. (2007). The Urban Design Reader. Routledge.

Latour, B. (1992). Where are the Missing Masses? Sociology of a Few Mundane Artefacts. In Shaping Technology, Building Society: Studies in Sociotechnical Change (pp. 225-258). Cambridge: Cambridge University Press.

Lazzarato, M. (2014). Signs and machines: capitalism and the production of subjectivity. (J. D. Jordan, Trans.). Los Angeles, CA: Semiotext(e). 
Lazzarato, M. (2015). Governing by Debt. South Pasadena, CA: Semiotext(e).

Lefebvre, H. (2011). The Production of Space. (D. Nicholson-Smith, Trans.) (Nachdr.). Malden, Mass.: Blackwell.

Lynch, K. (1981). A Theory of Good City Form. MIT Press,.

Madanipour, A. (1996). Design of Urban Space, an inquiry into a Socio-spatial Process. Chichester; New York: Wiley.

Madanipour, A. (2014). Urban Design, Space and Society. Basingstoke, Hampshire: Palgrave Macmillan.

Massumi, B. (1996). Becoming-Deleuzian. Environment and Planning D: Society and Space, 14(4), 395-406. https://doi.org/10.1068/d140395

McFarlane, C. (2011a). Assemblage and Critical Urbanism. City, 15(2), 204-224. https://doi.org/10.1080/13604813.2011.568715

McFarlane, C. (2011b). The city as assemblage: dwelling and urban space. Environment and Planning D: Society and Space, 29(4), 649-671. https://doi.org/10.1068/d4710

Moudon, A. V. (1992). A Catholic Approach to Organizing What Urban Designers Should Know. Journal of Planning Literature, 6(4), 331-349.

Norberg-Schulz, C. (1980). Genius Loci: towards a phenomenology of architecture. New York: Rizzoli.

Parr, A. (2010). The Deleuze Dictionary: 2nd Revised edition. Edinburgh: Edinburgh University Press.

Purcell, M. (2013). A New Land: Deleuze and Guattary and Planning. Planning Theory \& Practice, 14(1), 20-38.

Rankin, K. N. (2011). Assemblage and the Politics of Thick Description. City, 15(5), 563-569. https://doi.org/10.1080/13604813.2011.611287

Relph, E. (1976). Place and Placelessness. London: Pion Limited.

Rittel, H. W. J., \& Webber, M. M. (1973). Dilemmas in a General Theory of Planning. Policy Sciences, 4(2), 155-169. https://doi.org/10.1007/BF01405730

Rossi, A., \& Eisenman, P. (1982). The architecture of the city. Cambridge, Mass: MIT Press. 
Rydin, Y. (2014). The Challenges of the "Material Turn" for Planning Studies. Planning Theory \& Practice, 15(4), 590-595. https://doi.org/10.1080/14649357.2014.968007

Shane, D. G. (2005). Recombinant Urbanism: conceptual modeling in architecture, urban design, and city theory. Chichester, England; Hoboken, NJ: Wiley.

Sorkin, M. (2009). The End(s) of Urban Design. In A. Krieger \& W. Saunders (Eds.), Urban Design (pp. 155-188). University of Minnesota.

Sternberg, E. (2000). An Integrative Theory of Urban Design. Journal of the American Planning Association, 66(3), 265-278.

Trigg, D. (2012). The Memory of Place: a phenomenology of the uncanny. Athens: Ohio University Press.

Van Wezemael, J. (2008). The Contribution of Assemblage Theory and Minor Politics for Democratic Network Governance. Planning Theory, 7(2), 165-185.

https://doi.org/10.1177/1473095208090433

Wood, S. (2009). Desiring Docklands: Deleuze and Urban Planning Discourse. Planning Theory, 8(2), 191-216. https://doi.org/10.1177/1473095209102234

Young, E. B. (2013). The Deleuze and Guattari dictionary. New York: Bloomsbury Academic. 